\title{
Reclassification of the sulfate- and nitrate-reducing bacterium Desulfovibrio vulgaris subsp. oxamicus as Desulfovibrio oxamicus sp. nov., comb. nov.
}

\author{
Alejandro López-Cortés, ${ }^{1}$ Marie-Laure Fardeau, ${ }^{2}$ Guy Fauque, ${ }^{2,3}$ \\ Catherine Joulian ${ }^{4}$ and Bernard Ollivier ${ }^{2}$ \\ ${ }^{1}$ Laboratorio de Ecología Microbiana Molecular, Centro de Investigaciones Biológicas del \\ Noroeste (CIBNOR), Mar Bermejo 195, Playa Palo Santa Rita, La Paz, Baja California Sur, \\ 23090, Mexico \\ ${ }^{2}$ Laboratoire de Microbiologie IRD, Universités de Provence et de la Méditerranée, 163 avenue \\ de Luminy, ESIL-GBMA, Case 925, 13288 Marseille Cedex 9, France \\ ${ }^{3}$ Laboratoire de Microbiologie, Géochimie et Ecologie Marines, UMR CNRS 6117, Campus de \\ Luminy, Case 901, 13288 Marseille Cedex 9, France \\ ${ }^{4}$ BRGM, Environment and Process Division, Biotechnology Unit, 2, avenue Claude Guillemin, \\ 45060 Orléans Cedex 2, France
}

Correspondence

Bernard Ollivier

ollivier@esil.univ-mrs.fr
In addition to sulfate, sulfate-reducing bacteria (SRB) have been found to use many other mineral electron acceptors to oxidize $\mathrm{H}_{2}$ and organic compounds (Fauque \& Ollivier, 2004). Among them, the dissimilatory reduction of nitrate to ammonium has been poorly studied as few SRB have been reported to reduce nitrate as an alternative to sulfate (Moura et al., 1997). Within the SRB, members of the genera Desulfobulbus (e.g. Desulfobulbus propionicus; Widdel \& Pfennig, 1982), Desulforhopalus (e.g. Desulforhopalus singaporensis; Lie et al., 1999) and Desulfobacterium (e.g. Desulfobacterium catecholicum; Szewzyk \& Pfennig, 1987) and Desulfovibrio species have been shown to be able to utilize nitrate as a terminal electron acceptor. The latter species include Desulfovibrio desulfuricans, which has been isolated from various

Abbreviations: SRB, sulfate-reducing bacteria; SSU, small subunit. The GenBank/EMBL/DDBJ accession number for the 16S rRNA gene sequence of Desulfovibrio oxamicus DSM $1925^{\top}$ is DQ122124. ecosystems and particularly within the gut of a soil-feeding termite (Liu \& Peck, 1981; Steenkamp \& Peck, 1981; Keith \& Herbert, 1983; Seitz \& Cypionka, 1986; Brauman et al., 1990; Krekeler \& Cypionka, 1995; Costa et al., 1996), Desulfovibrio simplex isolated from an anaerobic sour whey digestor (Zellner et al., 1989), Desulfovibrio furfuralis isolated from a continuous fermenter culture treating the organic constituents of a sulfite evaparator condensate (Brune et al., 1983; Folkerts et al., 1989) and Desulfovibrio termitidis isolated from the hindgut of a termite (Brauman et al., 1990; Trinkerl et al., 1990). In all cases reported so far, dissimilatory reduction of nitrate by SRB leads to the formation of ammonium, with nitrite being an intermediary product of metabolism (Moura et al., 1997). Despite the fact that this reductive process prevails energetically over sulfate reduction (Thauer et al., 1977; Pietzsch \& Babel, 2003), little attention has been paid to it ecologically. One explanation for the lack of attention given to dissimilatory nitrate 
reduction by SRB may be that, in some cases, sulfate is preferred for use as a terminal electron acceptor when both sulfate and nitrate are present in the culture medium (Widdel \& Pfennig, 1982; Pietzsch \& Babel, 2003), thereby making nitrate reduction by SRB a marginal respiratory system within the ecosystems that they inhabit. Nevertheless, it has also been established that some SRB may (i) have a preference to use nitrate over sulfate as a terminal electron acceptor (Seitz \& Cypionka, 1986) or (ii) use the two electron acceptors simultaneously (Keith \& Herbert, 1983), thus making the real significance of nitrate reduction by SRB ambiguous in marine or terrestrial sediments.

We screened our collection of micro-organisms for SRB with the ability to use nitrate as a terminal electron acceptor. Interestingly, Desulfovibrio vulgaris subsp. oxamicus DSM $1925^{\mathrm{T}}$ was found to reduce nitrate to ammonium. This metabolic feature has only been attributed recently to this subspecies, as well as to another metabolically related SRB that can detoxify U(VI) (Pietzsch \& Babel, 2003). Therefore, we undertook additional experiments to characterize strain DSM $1925^{\mathrm{T}}$ phylogenetically and metabolically. Our results indicate that this subspecies is not phylogenetically related to the type strain of Desulfovibrio vulgaris and should be considered as a novel species of the genus Desulfovibrio.

Desulfovibrio vulgaris subsp. oxamicus DSM $1925^{\mathrm{T}}$ and Desulfovibrio termitidis DSM $5308^{\mathrm{T}}$ were used as reference cultures and were obtained from our laboratory collection of micro-organisms.

The Hungate technique (Hungate, 1969) was used throughout this study. Experiments were done using a basal medium containing per litre of distilled water: $1 \mathrm{~g} \mathrm{NH}_{4} \mathrm{Cl}, 0 \cdot 3 \mathrm{~g}$ $\mathrm{K}_{2} \mathrm{HPO}_{4}, 0 \cdot 3 \mathrm{~g} \mathrm{KH}_{2} \mathrm{PO}_{4}, 2 \cdot 0 \mathrm{~g} \mathrm{MgCl}_{2} \cdot 6 \mathrm{H}_{2} \mathrm{O}, 0 \cdot 1 \mathrm{~g} \mathrm{CaCl}_{2}$, $0.1 \mathrm{~g} \mathrm{KCl}, 1 \mathrm{~g} \mathrm{NaCl}, 0.5 \mathrm{~g}$ cysteine hydrochloride, $0.5 \mathrm{~g}$ yeast extract (Difco), $1 \mathrm{ml}$ trace mineral solution (Widdel \& Pfennig, 1982) and $1 \mathrm{mg}$ resazurin. The $\mathrm{pH}$ was adjusted to 7 with $10 \mathrm{M} \mathrm{KOH}$ and the medium was boiled under a stream of $\mathrm{O}_{2}$-free $\mathrm{N}_{2}$ gas and then cooled to room temperature. The medium was dispensed into serum bottles and Hungate tubes (20 and $5 \mathrm{ml}$, respectively), under a stream of $\mathrm{O}_{2}$-free $\mathrm{N}_{2}$ gas that was subsequently replaced by a mixture of $\mathrm{N}_{2} / \mathrm{CO}_{2}(80 / 20 \%, \mathrm{v} / \mathrm{v})$. The vessels were autoclaved for $45 \mathrm{~min}$ at $121{ }^{\circ} \mathrm{C}$ and sterile stock solutions of $\mathrm{Na}_{2} \mathrm{~S} .9 \mathrm{H}_{2} \mathrm{O}, \mathrm{NaHCO}_{3}$ and lactate (Difco) were injected prior to the inoculation of bacteria, to give final concentrations of $0.02 \%, 0.4 \%$ and $20 \mathrm{mM}$, respectively. Sodium sulfate or sodium nitrate $(20 \mathrm{mM})$ was used as the terminal electron acceptor.

Water baths were used to obtain incubation temperatures of up to $55^{\circ} \mathrm{C}$. For studies on $\mathrm{NaCl}$ requirement, $\mathrm{NaCl}$ was weighed directly in tubes prior to the medium being dispensed. The strains were subcultured at least once under the same experimental conditions prior to determination of growth rates. Substrates were tested at a final concentration of $20 \mathrm{mM}$.
Unless indicated otherwise, duplicate culture tubes were used throughout. Growth was measured by inserting the tubes directly into a model Cary 50 Scan spectrophotometer (Varian Corp.) and measuring the optical density at $580 \mathrm{~nm}$. Sulfide was determined photometrically as colloidal CuS by using the method of Cord-Ruwisch (1985). Fermentation products were determined as described by Miranda-Tello et al. (2003).

The $\mathrm{G}+\mathrm{C}$ content of the DNA was determined at the Deutsche Sammlung von Mikroorganismen und Zellkulturen (DSMZ), Braunschweig, Germany. DNA was isolated and purified by chromatography on hydroxyapatite using the procedure of Cashion et al. (1977) and the G+C content was determined by using HPLC, as described by Mesbah et al. (1989). Non-methylated lambda DNA (Sigma) was used as a standard.

DNA-DNA hybridization was performed at the DSMZ as described by De Ley et al. (1970), with the modification described by Escara \& Hutton (1980) and Huß et al. (1983), using a Gilford System model 2600 equipped with a Gilford model 2527-R thermoprogrammer and plotter. Renaturation rates were computed using the TRANSFER.BAS program (Jahnke, 1992).

The genomic DNA of strain DSM $1925^{\mathrm{T}}$ was extracted using a Wizard Genomic DNA Purification kit (Promega), and the almost complete small-subunit (SSU) 16S rRNA gene (positions 8-1494; Escherichia coli numbering) was amplified by PCR using the universal primers $8 \mathrm{~F}$ ( $5^{\prime}$-AGAGTTTGATCCTGGCTCAG-3') and 1492R (5'-GTCGTAACAAGGTAACCGTA-3'). The purified product (Nucleo Spin Extract kit; Macherey Nagel) was cloned using a pGEM-T Easy cloning kit (Promega). A plasmid containing the correct length insert was isolated using a Wizard Plus SV Minipreps DNA Purification System kit (Promega) and was sequenced by Genome Express.

The SSU rRNA gene sequence of strain DSM $1925^{\mathrm{T}}$ was aligned with sequences of related Desulfovibrio species obtained from GenBank (Benson et al., 1999), using the sequence aligner software from the Ribosomal Database Project II (Maidak et al., 2001) and the sequence alignment editor BioEdit (Hall, 1999). Positions of sequence and alignment uncertainty were omitted from the analysis. Pairwise evolutionary distances based on 1513 unambiguous nucleotides were computed using the method of Jukes \& Cantor (1969). A phylogenetic tree was constructed using the neighbour-joining method (Saitou \& Nei, 1987), with the SSU rRNA gene sequence of Desulfohalobium retbaense DSM $5692^{\mathrm{T}}$ as the outgroup. Confidence in the tree topology was determined by bootstrap analysis of 1000 resamplings of the sequences (Felsenstein, 1985). The phylogenetic programs were all implemented in the TREECON package (Van de Peer \& De Wachter, 1994).

A strain of Desulfovibrio that could use oxamate was isolated by J. R. Postgate in 1963 (Postgate, 1963) and was later 


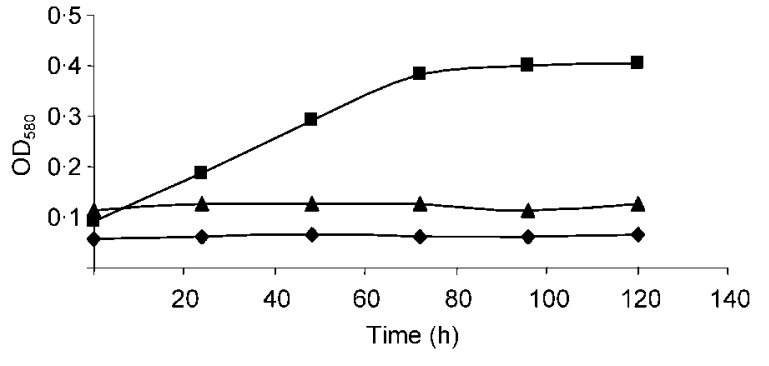

Fig. 1. Effect of nitrate reduction on growth of Desulfovibrio oxamicus sp. nov. DSM $1925^{\top}$. $\boldsymbol{\Delta}$, Lactate + nitrate without bacteria; $\boldsymbol{\sim}$, nitrate without lactate + bacteria; $\boldsymbol{\square}$, lactate + nitrate + bacteria.

recognized as a novel variety of Desulfovibrio vulgaris, Desulfovibrio vulgaris var. oxamicus (Postgate \& Campbell, 1966); the name D. vulgaris subsp. oxamicus was included in the Approved List (Skerman et al. 1980). In 1966, this strain $\left(\right.$ Monticello $2^{\mathrm{T}}$ ) presented a taxonomic problem to Postgate. Indeed, despite its DNA base composition, resistance to hibitane and its morphology, which clearly placed it in the Desulfovibrio vulgaris group, strain Monticello $2^{\mathrm{T}}$ had metabolic features (e.g. fermentation of choline and pyruvate) that resembled those of Desulfovibrio desulfuricans (Postgate \& Campbell, 1966). In addition, strain Monticello $2^{\mathrm{T}}$ differed from the type strain of Desulfovibrio vulgaris by its ability to metabolize oxamate and oxalate (Postgate \& Campbell, 1966).

Desulfovibrio vulgaris subsp. oxamicus DSM $1925^{\mathrm{T}}$ was recently reported to be a dissimilatory nitrate-reducing bacterium (Pietzsch \& Babel, 2003). We believe that this reductive process that we have confirmed in this study (Fig. 1) is of taxonomic relevance, as it is not shared by Desulfovibrio vulgaris Hildenborough ${ }^{\mathrm{T}}$ (Pietzsch \& Babel, 2003; this study). We have therefore undertaken additional experiments to characterize phenotypically, phylogenetically and genetically Desulfovibrio vulgaris subsp. oxamicus DSM $1925^{\mathrm{T}}$. In addition to hydrogen and formate, which are only oxidized in the presence of acetate as a carbon source as reported previously (Postgate \& Campbell, 1966), lactate, pyruvate, butanol, citrate and ethanol, but not glucose, fructose, acetate, propionate, butyrate, methanol, glycerol or peptone, were used as energy sources in the presence of sulfate as terminal electron acceptor. Lactate and ethanol were incompletely oxidized to acetate. In addition, strain DSM $1925^{\mathrm{T}}$ grew optimally at $37^{\circ} \mathrm{C}$ (temperature range for growth $\left.16-50{ }^{\circ} \mathrm{C}\right)$ and in the presence of $0 \cdot 1 \% \mathrm{NaCl}(\mathrm{NaCl}$ range for growth $0-5 \%)$. Strain DSM $1925^{\mathrm{T}}$ was only distantly related to the type strain of Desulfovibrio vulgaris subsp. vulgaris (95.4\% similarity of the SSU rRNA gene) and had Desulfovibrio termitidis $(99.4 \%$ similarity; Trinkerl et al., 1990) and Desulfovibrio longreachensis ( $98 \cdot 4 \%$ similarity; Redburn \& Patel, 1994) as its closest relatives (Fig. 2). Interestingly, both Desulfovibrio termitidis and Desulfovibrio longreachensis (Trinkerl et al., 1990; Redburn \& Patel, 1994), together with Desulfovibrio vulgaris subsp. oxamicus, reduce nitrate to ammonium, suggesting that comparative sequence analysis of SSU rRNA genes is highly discriminatory for distinguishing a clade of nitrate-SRB comprising the three isolates cited above within the genus Desulfovibrio.

As yet, we do not know the ecological significance of the ability of some SRB to reduce nitrate to ammonium, but we can hypothesize that, most probably, such SRB display this reductive process in sediments at lower redox potentials than those for sulfate reduction. In this respect, the role of nitrate-SRB in the global nitrogen cycle within the ecosystems they inhabit might have been underestimated. Of interest was the isolation from the hindgut of termites of two SRB that reduced nitrate (Desulfovibrio termitidis and 'Desulfovibrio desulfuricans subsp. termitidis') (Brauman et al., 1990; Trinkerl et al., 1990). In such an ecosystem, it has been hypothesized that these two organisms could act as hydrogen scavengers through interspecies hydrogen transfer with methanogens, during the degradation of highly reduced compounds such as benzoate and its relatives (Brauman et al., 1990). However, taking into account that nitrogen fixation has been demonstrated in termites (Breznak et al., 1973), our results suggest that nitratereducing Desulfovibrio species may interfere with nitrogen cycling in termites by incompletely oxidizing organic

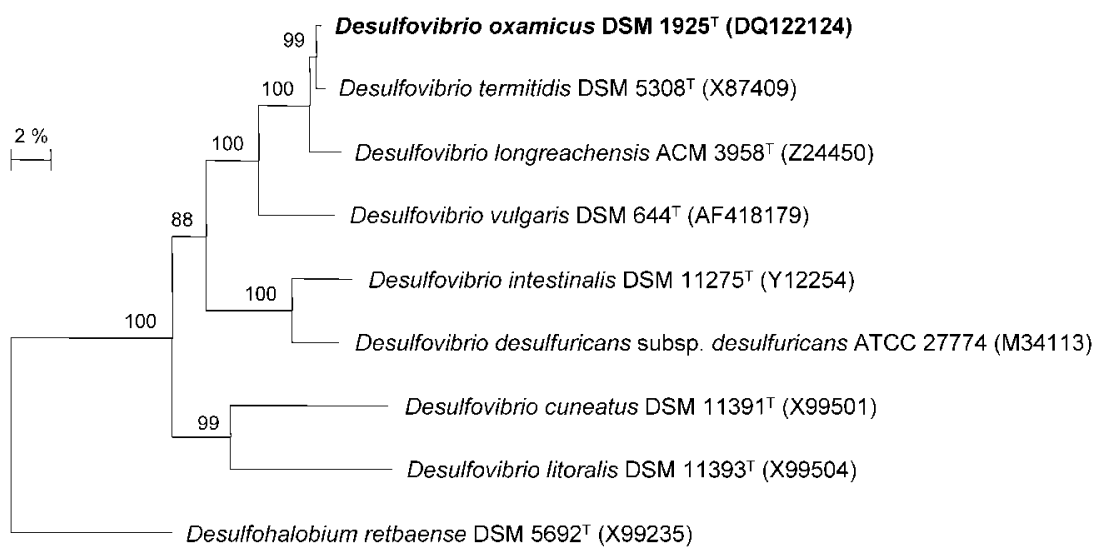

Fig. 2. Phylogenetic position of strain DSM $1925^{\top}$ within the genus Desulfovibrio, based on SSU rRNA gene sequences. Accession numbers of reference organisms are included. Percentage bootstrap values, based on 1000 replications, are shown at branch points. Bar, 2 nucleotide substitutions per 100 nucleotides. 
Table 1. Characteristics that differentiate Desulfovibrio oxamicus sp. nov. from Desulfovibrio termitidis and Desulfovibrio longreachensis

Taxa: 1, Desulfovibrio oxamicus sp. nov. DSM $1925^{\mathrm{T}}$ (data from this study); 2, Desulfovibrio termitidis (Trinkerl et al., 1990); 3, Desulfovibrio longreachensis (Redburn \& Patel, 1994). ND, Not determined.

\begin{tabular}{|lccc|}
\hline Characteristic & $\mathbf{1}$ & $\mathbf{2}$ & $\mathbf{3}$ \\
\hline Growth on sulfate with: & & & \\
$\quad$ Hydrogen & + & - & + \\
$\quad$ Sugars & - & + & - \\
$\quad$ Fumarate & - & $\mathrm{ND}$ & + \\
Temperature range for growth $\left({ }^{\circ} \mathrm{C}\right)$ & $16-50$ & $18-45$ & $20-48$ \\
Optimum temperature $\left({ }^{\circ} \mathrm{C}\right)$ & 37 & 35 & 37 \\
Highest NaCl concentration for & 5 & 2 & $\mathrm{ND}$ \\
growth $(\%)$ & & & \\
DNA G $+\mathrm{C}$ content $(\mathrm{mol} \%)$ & $65 \cdot 2$ & $67-68$ & 69 \\
\hline
\end{tabular}

compounds to acetate, which is an essential compound for the respiration of these insects (Brauman et al., 1990). Despite the existence of close phylogenetic similarities between Desulfovibrio termitidis, Desulfovibrio longreachensis and Desulfovibrio vulgaris subsp. oxamicus, the latter differs genomically from the other two Desulfovibrio species by having a lower G+C content of the DNA $[65 \cdot 2 \mathrm{~mol} \%$ for Desulfovibrio vulgaris subsp. oxamicus DSM $1925^{\mathrm{T}}$ (this study) versus $69 \mathrm{~mol} \%$ for Desulfovibrio longreachensis (Redburn \& Patel, 1994) and 67-68 mol\% for Desulfovibrio termitidis (Trinkerl et al., 1990)]. In addition, a DNADNA relatedness value of only $58 \%$ was obtained between Desulfovibrio vulgaris subsp. oxamicus DSM $1925^{\mathrm{T}}$ and its closest phylogenetic relative, Desulfovibrio termitidis DSM $5308^{\mathrm{T}}$. There are also major phenotypic differences that distinguish the two strains (Table 1). In contrast to Desulfovibrio termitidis, Desulfovibrio vulgaris subsp. oxamicus does not use sugars as an energy source and oxidizes hydrogen in the presence of acetate as a carbon source. Desulfovibrio longreachensis differs from Desulfovibrio vulgaris subsp. oxamicus by using fumarate in the presence and absence of sulfate as terminal electron acceptor and by the temperature range for growth.

Our results clearly indicate that Desulfovibrio vulgaris subsp. oxamicus is not a subspecies of Desulfovibrio vulgaris. With regard to genomic and phenotypic differences from its closest relatives, we propose that Desulfovibrio vulgaris subsp. oxamicus should be reclassified as Desulfovibrio oxamicus sp. nov., comb. nov.

\section{Description of Desulfovibrio oxamicus sp. nov., comb. nov.}

Desulfovibrio oxamicus (ox.am'i.cus. N.L. masc. adj. oxamicus pertaining to oxamic acid).

Basonym: Desulfovibrio vulgaris subsp. oxamicus Postgate and Campbell 1966.
The description of the species is the same as that given by Postgate (1984). Incompletely oxidizes lactate and ethanol to acetate. Oxidizes butanol, pyruvate and citrate, but not glucose, fructose, acetate, propionate, butyrate, methanol, glycerol or peptone. Optimum temperature for growth is $37^{\circ} \mathrm{C}$ (range $16-50{ }^{\circ} \mathrm{C}$ ). Optimum $\mathrm{NaCl}$ concentration for growth is $0 \cdot 1 \%$ (range $0-5 \%$ ). Reduces nitrate to ammonium.

The type strain is strain Monticello $2^{\mathrm{T}}\left(=\right.$ DSM $1925^{\mathrm{T}}=$ NCIMB $9442^{\mathrm{T}}=$ ATCC $33405^{\mathrm{T}}$ ).

\section{Acknowledgements}

A. L.-C. received financial support from the Département Soutien et Formation des Communautés Scientifiques du Sud (DSF)-Institut de Recherche pour le Développement (IRD), France, during his postdoctoral stay in Marseille, France.

\section{References}

Benson, D. A., Boguski, M. S., Lipman, D. J., Ostell, J., Ouellette, B. F. F., Rapp, B. A. \& Wheeler, D. L. (1999). GenBank. Nucleic Acids Res 27, 12-17.

Brauman, A., Koenig, J. F., Dutreix, J. \& Garcia, J. L. (1990). Characterization of two sulfate-reducing bacteria from the gut of the soil-feeding termite, Cubitermes speciosus. Antonie van Leeuwenhoek 58, 271-275.

Breznak, J. A., Brill, W. J., Mertins, J. W. \& Coppel, H. C. (1973). Nitrogen fixation in termites. Nature 244, 577-580.

Brune, G., Schoberth, S. M. \& Sahm, H. (1983). Growth of a strictly anaerobic bacterium on furfural (2-furaldehyde). Appl Environ Microbiol 46, 1187-1192.

Cashion, P., Holder-Franklin, M. A., McCully, J. \& Franklin, M. (1977). A rapid method for the base ratio determination of bacterial DNA. Anal Biochem 81, 461-466.

Cord-Ruwisch, R. (1985). A quick method for the determination of dissolved and precipitated sulfides in cultures of sulfate-reducing bacteria. J Microbiol Methods 4, 33-36.

Costa, V., Boopathy, R. \& Manning, J. (1996). Isolation and characterization of a sulfate-reducing bacterium that removed TNT (2,4,6-trinitrotoluene) under sulfate- and nitrate-reducing conditions. Bioresour Technol 56, 273-278.

De Ley, J., Cattoir, H. \& Reynaerts, A. (1970). The quantitative measurement of DNA hybridization from renaturation rates. Eur $J$ Biochem 12, 133-142.

Escara, J. F. \& Hutton, J. R. (1980). Thermal stability and renaturation of DNA in dimethyl sulfoxide solutions: acceleration of the renaturation rate. Biopolymers 19, 1315-1327.

Fauque, G. \& Ollivier, B. (2004). Anaerobes: the sulfate-reducing bacteria as an example of metabolic diversity. In Microbial Diversity and Bioprospecting, pp. 169-176. Edited by A. T. Bull. Washington, DC: American Society for Microbiology.

Felsenstein, J. (1985). Confidence limits on phylogenies: an approach using the bootstrap. Evolution 39, 783-791.

Folkerts, M., Ney, U., Kneifel, H., Stackebrandt, E., Witte, E. G., Förstel, H., Schoberth, S. M. \& Sahm, H. (1989). Desulfovibrio furfuralis sp. nov., a furfural degrading strictly anaerobic bacterium. Syst Appl Microbiol 11, 161-169. 
Hall, T. A. (1999). BioEdit: a user-friendly biological sequence alignment editor and analysis program for Windows 95/98/NT. Nucleic Acids Symp Ser 41, 95-98.

Hungate, R. E. (1969). A roll-tube method for the cultivation of strict anaerobes. Methods Microbiol 3B, 117-132.

Huß, V. A. R., Festel, H. \& Schleifer, K. H. (1983). Studies on the spectrometric determination of DNA hybridization from renaturation rates. Syst Appl Microbiol 4, 184-192.

Jahnke, K.-D. (1992). BASIC computer program for evaluation of spectroscopic DNA renaturation data from GILFORD SYSTEM 2600 spectrophotometer on a PC/XT/AT type personal computer. J Microbiol Methods 15, 61-73.

Jukes, T. H. \& Cantor, C. R. (1969). Evolution of protein molecules. In Mammalian Protein Metabolism, vol. 3, pp. 21-132. Edited by H. N. Munro. New York: Academic Press.

Keith, S. M. \& Herbert, R. A. (1983). Dissimilatory nitrate reduction by a strain of Desulfovibrio desulfuricans. FEMS Microbiol Lett 18, 55-59.

Krekeler, D. \& Cypionka, H. (1995). The preferred electron acceptor of Desulfovibrio desulfuricans CSN. FEMS Microbiol Ecol 17, 271-278.

Lie, T. J., Clawson, M. L., Godchaux, W. \& Leadbetter, E. R. (1999). Sulfidogenesis from 2-aminoethanesulfonate (taurine) fermentation by a morphologically unusual sulfate-reducing bacterium, Desulforhopalus singaporensis sp. nov. Appl Environ Microbiol 65, 3328-3334.

Liu, M.-C. \& Peck, H. D., Jr (1981). The isolation of a hexaheme cytochrome from Desulfovibrio desulfuricans and its identification as a new type of nitrite reductase. J Biol Chem 256, 13159-13164.

Maidak, B. L., Cole, J. R., Lilburn, T. G. \& 7 other authors (2001). The RDP-II (Ribosomal Database Project). Nucleic Acids Res 29, 173-174.

Mesbah, M., Premachandran, U. \& Whitman, W. B. (1989). Precise measurement of the $\mathrm{G}+\mathrm{C}$ content of deoxyribonucleic acid by highperformance liquid chromatography. Int J Syst Bacteriol 39, 159-167.

Miranda-Tello, E., Fardeau, M.-L., Sepúlveda, J., Fernández, L., Cayol, J. L., Thomas, P. \& Ollivier, B. (2003). Garciella nitratireducens gen. nov., sp. nov., an anaerobic, thermophilic, nitrate- and thiosulfate-reducing bacterium isolated from an oilfield separator in the Gulf of Mexico. Int J Syst Evol Microbiol 53, 1509-1514.

Moura, I., Bursakov, S., Costa, C. \& Moura, J. J. G. (1997). Nitrate and nitrite utilization in sulfate-reducing bacteria. Anaerobe 3, 279-290.

Pietzsch, K. \& Babel, W. (2003). A sulfate-reducing bacterium that can detoxify $\mathrm{U}(\mathrm{VI})$ and obtain energy via nitrate reduction. $J$ Basic Microbiol 43, 348-361.
Postgate, J. R. (1963). A strain of Desulfovibrio able to use oxamate. Arch Mikrobiol 46, 287-295.

Postgate, J. R. (1984). Genus Desulfovibrio Kluyver and van Niel 1936, 397 ${ }^{\mathrm{AL}}$. In Bergey's Manual of Systematic Bacteriology, vol. 1, pp. 666-672. Edited by N. R. Krieg \& J. G. Holt. Baltimore: Williams \& Wilkins.

Postgate, J. R. \& Campbell, L. L. (1966). Classification of Desulfovibrio species, the nonsporulating sulfate-reducing bacteria. Bacteriol Rev 30, 732-738.

Redburn, A. C. \& Patel, B. K. C. (1994). Desulfovibrio longreachii sp. nov., a sulfate-reducing bacterium isolated from the Great Artesian Basin of Australia. FEMS Microbiol Lett 115, 33-38.

Saitou, N. \& Nei, M. (1987). The neighbor-joining method: a new method for reconstructing phylogenetic trees. Mol Biol Evol 4, $405-425$.

Seitz, H.-J. \& Cypionka, H. (1986). Chemolithotrophic growth of Desulfovibrio desulfuricans with hydrogen coupled to ammonification of nitrate or nitrite. Arch Microbiol 146, 63-67.

Skerman, V. B. D., McGowan, V. \& Sneath, P. H. A. (1980). Approved Lists of Bacterial Names. Int J Syst Bacteriol 30, 225-420.

Steenkamp, D. J. \& Peck, H. D., Jr (1981). Proton translocation associated with nitrite respiration in Desulfovibrio desulfuricans. J Biol Chem 256, 5450-5458.

Szewzyk, R. \& Pfennig, N. (1987). Complete oxidation of catechol by the strictly anaerobic sulfate-reducing Desulfobacterium catecholicum sp. nov. Arch Microbiol 147, 163-168.

Thauer, R. K., Jungermann, K. \& Decker, K. (1977). Energy conservation in chemotrophic anaerobic bacteria. Bacteriol Rev 41, 100-180.

Trinkerl, M., Breunig, A., Schauder, R. \& König, H. (1990). Desulfovibrio termitidis sp. nov., a carbohydrate-degrading sulfatereducing bacterium from the hindgut of a termite. Syst Appl Microbiol 13, 372-377.

Van de Peer, Y. \& De Wachter, R. (1994). TREECON for Windows: a software package for the construction and drawing of evolutionary trees for the Microsoft Windows environment. Comput Appl Biosci 10, 569-570.

Widdel, F. \& Pfennig, N. (1982). Studies on dissimilatory sulfatereducing bacteria that decompose fatty acids. II. Incomplete oxidation of propionate by Desulfobulbus propionicus gen. nov., sp. nov. Arch Microbiol 131, 360-365.

Zellner, G., Messner, P., Kneifel, H. \& Winter, J. (1989). Desulfovibrio simplex spec. nov., a new sulfate-reducing bacterium from a sour whey digester. Arch Microbiol 152, 329-334. 